\title{
Genotype-specific requirements for in vitro culture initiation and multiplication of Magnolia taxa
}

\author{
Jana Konôpková ${ }^{1}$, Dominika Košútová ${ }^{1,2^{*}}$, Peter Ferus ${ }^{1}$ \\ ${ }^{1}$ Mlyňany Arboretum, Institute of Forest Ecology, Slovak Academy of Sciences, Vieska nad Žitavou 178, \\ SK-95152 Slepčany, Slovakia \\ ${ }^{2}$ Department of Botany and Genetics, Faculty of Natural Sciences, University of Constantine the Philosopher, \\ Nábrežie mládeže 91, SK-949 74 Nitra, Slovakia
}

\begin{abstract}
Konôpková, J., Košútová, D., Ferus, P., 2020. Genotype-specific requirements for in vitro culture initiation and multiplication of Magnolia taxa. Folia Oecologica, 47 (1): 34-44.

The influence of basal media composition, concentration of plant growth regulators (PGRs), and the developmental stage of primary explants (dormancy, stage of bud opening and fruit ripening) on the initiation phase of nine Magnolia genotypes, including M. stellata /Sieb. \& Zucc./Maxim., M. × soulangeana 'Rustica Rubra', M. denudata Desr., M. × soulangeana 'Alexandrina', M. liliiflora Desr., M. officinalis var. biloba Rehd. \& Wils., M. salicifolia Maxim., M. × soulangeana 'Lennei', and M. kobus DC, was evaluated. The highest efficiency of primary culture initiation of seven Magnolia genotypes (except for M. liliiflora and M. salicifolia) was achieved from primary explants collected in the bud opening stage. A high positive correlation was found between total tannins and efficiency of the primary culture initiation at the fruit ripening stage $(\mathrm{r}=0.833)$. Standardi and Catalano medium $\left(\mathrm{S}_{2}\right)$ with $0.5 \mathrm{mg} \mathrm{l}^{-1}$ of 6-benzylaminopurine (BAP) was the most appropriate for multiplication of $M . \times$ soulangeana 'Alexandrina', whereas tissue cultures of $M . \times$ soulangeana 'Lennei' proliferated and grew better on $\mathrm{S}_{2}$ medium with $1.0 \mathrm{mg} \mathrm{l}^{-1}$ of BAP and $1.0 \mathrm{~g} \mathrm{l}^{-1}$ of polyvinylpyrrolidone. The requirements for the composition of basal media and concentration of PGRs in the initiation and multiplication stages of micropropagation of various Magnolia species and cultivars are genotype-specific.
\end{abstract}

\section{Keywords}

in vitro propagation, Magnolia, multiplication, primary culture initiation

\section{Introduction}

The genus Magnolia L. consists of over 250 species and numerous hybrids and cultivars (CALLAWAY, 1994; Figlar and Noотевоом, 2004). Most species come from temperate and tropical climatic regions of Southeast Asia, but some species come from the American continent. The distribution area of the American magnolias (e.g. M. acuminata /L./ L., M. virginiana L., M. macrophylla Michx., M. tripetala /L./ L.) extends through southern Canada, into the United States and to western Mexico. Asian magno- lias (e.g. M. denudata Desr., M. kobus DC. M. liliiflora Desr.) are naturally distributed throughout China, Korea, Japan, the Himalayas, Java and Malaysia (KAMENICKÁ and VÁLKA, 1997).

Trees and shrubs of the genus Magnolia are usually grown as ornamental plants because of their decorative leaves and large attractive flowers, which vary in color (from white to dark violet) size, shape and fragrance. Cultivars of $M . \times$ soulangeana are the most widespread magnolias in Slovakia (KAMENICKÁ and VÁLKA, 1997). Magnolias can be propagated generatively (by seeds) or

*Corresponding author: 
vegetatively (via layering, grafting, rooting of stem cuttings), but the germination rate of seeds and the rooting ability of cuttings is typically very low. Therefore, propagation of magnolias using in vitro tissue cultures techniques is considered very appropriate (CALLAWAY, 1994; KAMENICKÁ and VÁLKA, 1997; Ming and HuAn-ChEng, 2003).

Previous studies on in vitro propagation of magnolias were focused on conservation and commercial purposes; as examples: M. stellata (BIEDERMAN. 1987; RADOMIR, 2012), M. denudata (BI et al., 2002), M. liliiflora (SoKoLOV et al., 2014; FILOvá et al., 2018a), M. officinalis (ToNG et al., 2002), M. salicifolia (KAMENICKÁ and VÁLKA, 1997) and M. × soulangeana (KAMENICKÁ and LANÁKOvÁ, 2000; KonôPKová, 2007; RADOMIR, 2012; SoKolov et al. 2014; Wojtania et al. 2015; Filoví et al., 2018b).

The results of in vitro propagation depend on various external and internal factors, such as developmental stage of primary explants, age of donor plants, composition of the cultivation medium and cultivation conditions (Owen and Miller, 1992). Individual magnolia taxa have different requirements for the composition of the cultivation medium (Kamenické and LANÁKová, 2000). The successful initiation and development of Magnolia tissue culture was reported for various basal cultivation media, such as Murashige and Skoog (1962), Standardi and CATAlano (1985), woody plant medium - WPM (Lloyd and MCCOWN, 1980), rhododendron medium (ANDERSON, 1980), B5 medium (GAMBORG et al., 1968) and vitis medium (ChÉE and Pool, 1987) (KAMENICKÁ and LaNÁKová, 2000; PARris et al., 2012; SoKolov et al., 2014; WoJTANiA et al., 2015).

Numerous works refer to the difficulties of in vitro propagation in magnolias (BIEDERMANN, 1987; PARRIS et al., 2012; WoJTANiA et al., 2015). The main problems are browning of explants, hyperhydricity and low activity of axillary buds (BIEDERMAN, 1987; SoKolov et al., 2014). Media browning caused by the presence of phenolic compounds is another complication in the Magnolia micropropagation process. Many of this substances are toxic and cause growth inhibition or death of the cultures. There are options to reduce phenolics in the cultivation media, like the addition of antioxidants (e.g. citric acid or ascorbic acid) and adsorbents (activated charcoal, polyvinylpyrolidone) to media and frequent sub-cultivation to a fresh medium (Kester et al., 2002).

The main objective of this study was to formulate genotype-specific methods for the successful initiation of primary in vitro cultures for Magnolia micropropagation based on basal media composition, cytokinin and auxin concentrations, and the donor plant developmental stage in nine Magnolia genotypes (M. stellata /Sieb. \&Zucc./ Maxim., M. × soulangeana 'Rustica Rubra', M. denudata Desr., $M . \times$ soulangeana 'Alexandrina', M. liliiflora Desr., M. officinalis var. biloba Rehd. \& Wils., M. salicifolia Maxim., M. × soulangeana 'Lennei' and M. kobus DC). The influence of the concentration of 6-benzylaminopurine and polyvinylpyrrolidone in multiplication media on the growth and development of in vitro cultures of two Magnolia genotypes (M. × soul. 'Alexandrina' and M. × soul. 'Lennei') was examined, as well as analysis of metabolic markers associated with explant fitness.

\section{Materials and methods}

\section{Donor plant characterization}

Plant material for initiation of primary in vitro cultures and metabolic analyses of donor plants was taken from magnolia trees growing in Mlyňany Arboretum, Institute of Forest Ecology, Slovak Academy of Sciences (Mlyňany Arboretum IFE SAS) and in a private garden in Lučenec town (Table 1).

\section{Mlyňany Arboretum IFE SAS}

Mlyňany Arboretum SAS is situated in western Slovakia, on the northern edge of the Danubian Lowland in the valley of the Žitava river and the southern margin of the Tribeč and Pohronský Inovec mountains. The arboretum terrain is slightly undulating with a range of 160-204 m a.s.l. (TÁBOR and PAVLAČKA, 1992). Typically for this area, the soils of lowlands and basins are brown (brunisols) to illimerized soils (luvisols) on loess (MichaLKo, 1986). In some parts of the arboretum, there are also podzolic soils (TÁBOR and PAVLAČKA, 1992). In a recent study, Polláková (2018) identified three reference soil groups (RSG) in the Mlyňany Arboretum, namely luvisols, retisols and chernozems.

The Mlyňany Arboretum belongs to the warmest and driest region of Slovakia and the average annual temperature is $9.8^{\circ} \mathrm{C}$ with an average annual rainfall of $577.1 \mathrm{~mm}$ (long-term average of 1961-2011). According to the longterm monitoring of temperature conditions, the warmest month is July, with an average temperature $20.1{ }^{\circ} \mathrm{C}$ and the coldest month is January $\left(-1.2^{\circ} \mathrm{C}\right)$. The area is characterized by a prolonged dry season at the peak of summer, often almost without precipitation (HoŤKA and BARTA, 2012).

\section{Private garden in Lučenec}

The town of Lučenec is in the western part of the Lučenec Basin, which is part of the Southern Slovak Basin. The altitude of the town centre is $194 \mathrm{~m}$ a.s.l., the entire town cadastre lies at an altitude of 170-272 m a.s.1. (KolimÁrová et al., 2016). Typically, the area has illimerized to gleyed soils on polygenic clays and brown forest soils on silicate rocks (MAGIC, 1986).

The area of Lučenec is a warm, slightly dry region with an average annual temperature of $9.1^{\circ} \mathrm{C}$ and an annual rainfall of 550-650 mm. The coldest month is January, with an average temperature of $-3{ }^{\circ} \mathrm{C}$ and the warmest month is July, which has an average temperature around $20{ }^{\circ} \mathrm{C}$ (Kolimároví et al., 2016).

\section{Donor plant analyses}

Fully developed leaves for further analyses were collected at the fruit ripening stage (September 2018, BBCH81). Plant material was collected from illuminated parts of the crown in the morning hours (10:00-11:00 am). 
Table 1. List of donor plants

\begin{tabular}{|c|c|c|c|c|}
\hline Species/Cultivar & Origin & Location & GPS coordinates & Age \\
\hline $\begin{array}{l}\text { Magnolia stellata } \\
\text { /Sieb. \& Zucc./ } \\
\text { Maxim. }\end{array}$ & $\begin{array}{l}\text { Japan - central part } \\
\text { of Honshu island }\end{array}$ & $\begin{array}{l}\text { MA - Ambrózy's } \\
\text { Semper vireo park }\end{array}$ & $\begin{array}{l}48^{\circ} 19^{\prime} 13.8^{\prime \prime} \mathrm{N} \\
18^{\circ} 22^{\prime} 10.2^{\prime \prime} \mathrm{E}\end{array}$ & Mature tree \\
\hline $\begin{array}{c}\text { Magnolia } \times \\
\text { soulangeana 'Rustica } \\
\text { Rubra' }\end{array}$ & - & $\begin{array}{l}\text { MA - Ambrózy's } \\
\text { Semper vireo park }\end{array}$ & $\begin{array}{l}48^{\circ} 19^{\prime} 10.6^{\prime \prime} \mathrm{N} \\
18^{\circ} 22^{\prime} 06.8^{\prime \prime} \mathrm{E}\end{array}$ & 13 years \\
\hline $\begin{array}{c}\text { Magnolia denudata } \\
\text { Desr. }\end{array}$ & $\begin{array}{c}\text { China - Jiangsu, } \\
\text { Anhui, Zhejiang, } \\
\text { Jiangxi, Fujian, } \\
\text { Guangdong, Guangxi, } \\
\text { Guizhou and Hunan } \\
\text { provinces }\end{array}$ & $\begin{array}{l}\text { MA - East Asian } \\
\text { dendroflora }\end{array}$ & $\begin{array}{l}48^{\circ} 18^{\prime} 59.3^{\prime \prime} \mathrm{N} \\
18^{\circ} 22^{\prime} 01.1^{\prime \prime} \mathrm{E}\end{array}$ & Approx. 55 years \\
\hline $\begin{array}{l}\text { Magnolia } \times \\
\text { soulangeana } \\
\text { 'Alexandrina' }\end{array}$ & - & Lučenec & $\begin{array}{l}48^{\circ} 19^{\prime} 14.9^{\prime \prime} \mathrm{N} \\
19^{\circ} 40^{\prime} 29.0^{\prime \prime} \mathrm{E}\end{array}$ & $40-45$ years \\
\hline $\begin{array}{c}\text { Magnolia liliiflora } \\
\text { Desr. }\end{array}$ & Central China & Lučenec & $\begin{array}{l}48^{\circ} 19^{\prime} 14.9^{\prime \prime} \mathrm{N} \\
19^{\circ} 40^{\prime} 28.8^{\prime \prime} \mathrm{E}\end{array}$ & $40-45$ years \\
\hline $\begin{array}{c}\text { Magnolia officinalis } \\
\text { var. biloba Rehd. } \\
\text { \&Wils. }\end{array}$ & $\begin{array}{l}\text { China - Hubei and } \\
\text { Sichuan provinces }\end{array}$ & $\begin{array}{c}\mathrm{MA}-\text { old } \\
\text { experimental section }\end{array}$ & $\begin{array}{l}48^{\circ} 19^{\prime} 22.4^{\prime \prime} \mathrm{N} \\
18^{\circ} 21^{\prime} 49.7^{\prime \prime} \mathrm{E}\end{array}$ & Approx. 55 years \\
\hline $\begin{array}{c}\text { Magnolia salicifolia } \\
\text { Maxim. }\end{array}$ & $\begin{array}{c}\text { Japan - Honshu, } \\
\text { Shikoku and Kyushu } \\
\text { islands }\end{array}$ & $\begin{array}{l}\text { MA - Ambrózy's } \\
\text { Semper vireo park }\end{array}$ & $\begin{array}{l}48^{\circ} 19^{\prime} 14.5^{\prime \prime} \mathrm{N} \\
18^{\circ} 22^{\prime} 10.4^{\prime \prime} \mathrm{E}\end{array}$ & Mature tree \\
\hline $\begin{array}{c}\text { Magnolia } \times \\
\text { soulangeana 'Lennei' }\end{array}$ & - & MA - nurseries & $\begin{array}{l}48^{\circ} 19^{\prime} 20.1^{\prime \prime} \mathrm{N} \\
18^{\circ} 22^{\prime} 03.2^{\prime \prime} \mathrm{E}\end{array}$ & Mature tree \\
\hline Magnolia kobus DC. & $\begin{array}{c}\text { Japan, except } \\
\text { Shikoku island }\end{array}$ & $\begin{array}{l}\text { MA - East Asian } \\
\text { dendroflora }\end{array}$ & $\begin{array}{l}48^{\circ} 18^{\prime} 59.0^{\prime \prime} \mathrm{N} \\
18^{\circ} 22^{\prime} 01.6^{\prime \prime} \mathrm{E}\end{array}$ & Approx. 40 years \\
\hline
\end{tabular}

MA, Mlyňany Arboretum IFE SAS.

\section{Chlorophyll a+b}

Approximately $0.1 \mathrm{~g}$ of fresh leaf tissue was homogenized with sea sand, anhydrous magnesium carbonate and $80 \%$ acetone. The mixture was quantitatively transferred into test tubes and filtered using a vacuum pump. Filtrate absorbance was measured [Jasco-V600 (Jasco Inc., Japan)] at $647 \mathrm{~nm}$ (chlb) and $663 \mathrm{~nm}$ (chla) wavelengths. The concentration of photosynthetic pigments were calculated according to LICHTENTAHLER (1987).

\section{Hydrogen peroxide}

Approximately $0.1 \mathrm{~g}$ of fresh leaf tissue was homogenized in $6 \mathrm{ml}$ of cold acetone, quantitatively transferred into test tubes and centrifuged at $6,000 \mathrm{rpm}$ for 5 minutes. Two $\mathrm{ml}$ of the supernatant was added to $0.8 \mathrm{ml}$ of titanium reagent $\left[0.04 \%(\mathrm{w} / \mathrm{v}) \mathrm{Ti}^{4+}\right.$ in $\mathrm{Ti}\left(\mathrm{SO}_{4}\right)$ form $]$ and $1 \mathrm{ml}$ of concentrated $(30 \%)$ ammonia. The reaction mixture was mixed thoroughly and centrifuged at $6,000 \mathrm{rpm}$ for 10 minutes. The upper layer of the mixture was discarded and the bottom layer (containing $\mathrm{Ti}-\mathrm{H}_{2} \mathrm{O}_{2}$ crystals) was supplemented with $2 \mathrm{ml}$ of $2 \mathrm{M}$ sulphuric acid. After syringe filtration (0.2 $\mu \mathrm{m}$ PTFE membrane), absorbance was measured at $415 \mathrm{~nm}$ (MukHerJeE and ChOUdHuRi, 1983).

\section{Total phenolic acids, flavonoids and tannins}

Approximately $0.1 \mathrm{~g}$ of fresh plant material was homogenized using a mortar and pestle with sea sand and $2 \mathrm{ml}$ of deionized water. The mixture was quantitatively transferred into test tubes and the volume was adjusted to $6 \mathrm{ml}$. Test tubes were centrifuged at $6,000 \mathrm{rpm}$ for 15 minutes. Prepared water extracts were kept frozen for subsequent analysis of total phenolic acids, flavonoids and tannins.

\section{Phenolic acids}

After warming the water extracts to room temperature, components of the reaction mixture were added into the test tubes in the following order: $50 \mu \mathrm{l}$ of water extract, $450 \mu \mathrm{l}$ of deionized water, $250 \mu \mathrm{l}$ of Folin-Ciocalteau reagent and $1.25 \mathrm{ml}$ of $20 \%$ sodium carbonate (w/v). After a thorough mixing, samples were incubated at laboratory temperature for 20 minutes. The absorbance of samples was measured at $735 \mathrm{~nm}$ (NGUYEN and NiEMEYER, 2008).

\section{Flavonoids}

A $0.4 \mathrm{ml}$ aliquot of water extract was added to $0.2 \mathrm{ml}$ of $10 \%$ aluminium nitrate $(\mathrm{w} / \mathrm{v}), 0.2 \mathrm{ml}$ of $1 \mathrm{M}$ potassium acetate and $8 \mathrm{ml}$ of $80 \%$ ethanol. After 40 minutes of incuba- 
tion at laboratory temperature, the absorbance of the reaction mixture was determined at $415 \mathrm{~nm}$ (PARK et al., 1997).

\section{Tannins}

One millilitre of the water extract was mixed with $5 \mathrm{ml}$ of deionized water, $1 \mathrm{ml}$ of $0.35 \%$ brown ammonium iron (III) citrate (w/v), and $1 \mathrm{ml}$ of $0.8 \%(\mathrm{v} / \mathrm{v})$ ammonia. Absorbance of reaction mixtures was measured at $525 \mathrm{~nm}$ after 10 minutes of incubation at laboratory temperature (ÚKZÚZ, 2013).

\section{In vitro propagation}

\section{Composition of the cultivation media}

Two basal cultivation media, MS (Murashige and SKoog, 1962) and $\mathrm{S}_{2}$ (Standardi and Catalano, 1985), with modifications, SA and SB (Table 2), were used for cultivation of in vitro cultures. Sucrose $\left(20 \mathrm{~g} \mathrm{l}^{-1}\right)$ and agar $\left(7 \mathrm{~g} \mathrm{l}^{-1}\right.$; Agar Bios Special LL, Biolife) were added and $\mathrm{pH}$ was adjusted to 5.6. Prepared media were poured into glass jars with a membranous filter and autoclaved at $121^{\circ} \mathrm{C}$ and $120 \mathrm{kPa}$ pressure for 20 minutes.

Four modifications of the MS medium (MS1-MS4) and two modifications of the $\mathrm{S}_{2}$ medium (SA1, SB1), supplemented with 6-Benzylaminopurine (BAP) and 1-Naphthaleneacetic acid (NAA), were used for initiation of primary tissue cultures (Table 3 ). As a protection against possible contamination of primary cultures, $1 \mathrm{ml} \mathrm{l}^{-1}$ of Plant Preservative Mixture (PPM; Plant Cell Technology) was added into initiation media.

For multiplication, four modifications of the $\mathrm{S}_{2}$ medium (SAB0.5, SAB1, SAB0.5-PVP and SAB1-PVP), supplemented with 0.5 or $1 \mathrm{mg} \mathrm{l}^{-1}$ of BAP, were applied (Table 4). Polyvinylpyrrolidone (PVP), as an absorbent of phenolic compounds in growth media, was added to two modifications (SAB0.5-PVP, SAB1-PVP) of the multiplication medium.

Table 2. Composition of basal cultivation media

\begin{tabular}{|c|c|c|c|c|}
\hline & & \multirow{2}{*}{$\begin{array}{c}\mathrm{MS} \\
\left(\mathrm{mg} \mathrm{l}^{-1}\right)\end{array}$} & \multicolumn{2}{|c|}{$\mathrm{S}_{2}$} \\
\hline & & & $\begin{array}{c}\text { SA } \\
\left(\mathrm{mg} \mathrm{l}^{-1}\right)\end{array}$ & $\begin{array}{c}\mathrm{SB} \\
\left(\mathrm{mg} \mathrm{l}^{-1}\right)\end{array}$ \\
\hline \multirow{7}{*}{ Macroelements } & $\mathrm{CaCl}_{2} \cdot 2 \mathrm{H}_{2} \mathrm{O}$ & 440 & - & - \\
\hline & $\mathrm{Ca}\left(\mathrm{NO}_{3}\right)_{2} \cdot 4 \mathrm{H}_{2} \mathrm{O}$ & - & 1,200 & 1,200 \\
\hline & $\mathrm{KH}_{2} \mathrm{PO}_{4}$ & 170 & 270 & 270 \\
\hline & KNO3 & 1,900 & 1,800 & 1,800 \\
\hline & $\mathrm{MgSO}_{4}$ & 181 & 360 & 360 \\
\hline & $\mathrm{NH}_{4} \mathrm{NO}_{3}$ & 1,650 & 400 & 400 \\
\hline & FeNaEDTA & 36.7 & 36.7 & 36.7 \\
\hline \multirow{7}{*}{ Microelements } & $\mathrm{H}_{3} \mathrm{BO}_{3}$ & 6.2 & 10 & 6.2 \\
\hline & $\mathrm{MnSO}_{4} \cdot \mathrm{H}_{2} \mathrm{O}$ & 16.9 & 18 & 1 \\
\hline & $\mathrm{Na}_{2} \mathrm{MoO}_{4} \cdot 2 \mathrm{H}_{2} \mathrm{O}$ & 0.44 & 0.25 & 0.25 \\
\hline & $\mathrm{ZnSO}_{4} .7 \mathrm{H}_{2} \mathrm{O}$ & 8.6 & 10 & 8.6 \\
\hline & $\mathrm{CuSO}_{4} .5 \mathrm{H}_{2} \mathrm{O}$ & 0.025 & 0.025 & 0.025 \\
\hline & $\mathrm{CoCl}_{2} .6 \mathrm{H}_{2} \mathrm{O}$ & 0.025 & - & 0.025 \\
\hline & $\mathrm{KI}$ & 0.83 & - & 0.08 \\
\hline \multirow{8}{*}{ Vitamins } & Myoinositol & 100 & 100 & 100 \\
\hline & Glycine & 2 & 2 & - \\
\hline & Nicotinic acid & 0.5 & 5 & - \\
\hline & Pyridoxine hydrochloride & 0.5 & 0.5 & - \\
\hline & Thiamine hydrochloride & 0.1 & 0.5 & 4 \\
\hline & Folic acid & - & 0.5 & - \\
\hline & Biotin & - & 0.65 & - \\
\hline & & $\left(\mathrm{g} \mathrm{l}^{-1}\right)$ & $\left(\mathrm{g} \mathrm{l}^{-1}\right)$ & $\left(\mathrm{g} \mathrm{l}^{-1}\right)$ \\
\hline \multirow{2}{*}{ Organic substances } & Sucrose & 20 & 20 & 20 \\
\hline & Agar & 7 & 7 & 7 \\
\hline $\mathrm{pH}$ & & 5.6 & 5.6 & 5.6 \\
\hline
\end{tabular}

Media full names and abbreviations: Murashige and Skoog (MS), Standardi and Catalano $\left(\mathrm{S}_{2}\right)$, modifications of $\mathrm{S}_{2}$ medium (SA, SB). 
Table 3. Cultivation media for initiation of primary cultures

\begin{tabular}{ccccc}
\hline & & \multicolumn{2}{c}{ Growth regulators } \\
Cultivation medium & & BAP $\left(\mathrm{mg} \mathrm{l}^{-1}\right)$ & NAA $\left(\mathrm{mg} \mathrm{1}^{-1}\right)$ \\
\hline SA & SA1 & 1.0 & 0.1 \\
SB & SB1 & 1.0 & 0.1 \\
& MS1 & 0.25 & - \\
MS & MS2 & 0.5 & 0.25 \\
& MS3 & 0.25 & 0.25 \\
\hline
\end{tabular}

Media full names and abbreviations: Murashige and Skoog (MS), modification of Standardi and Catalano medium (SA, SB). Growth regulators are presented in final amounts: 6-benzylaminopurine (BAP) and 1-naphthaleneacetic acid (NAA).

Table 4. Cultivation media for multiplication of in vitro cultures

\begin{tabular}{cccc}
\hline \multicolumn{2}{c}{ Cultivation medium } & $\begin{array}{c}\text { Growth regulator } \\
\text { BAP } \\
\left(\mathrm{mg} \mathrm{l}^{-1}\right)\end{array}$ & $\begin{array}{c}\text { Absorbent of phenolic compounds } \\
\text { PVP } \\
\left(\mathrm{g} \mathrm{l}^{-1}\right)\end{array}$ \\
\hline \multirow{2}{*}{ SA } & SAB0.5 & 0.5 & - \\
& SAB0.5-PVP & 0.5 & 1.0 \\
& SAB1 & 1.0 & - \\
\hline
\end{tabular}

Media full names and abbreviations: modification of Standardi and Catalano medium (SA). Growth regulator (6-benzylaminopurine, BAP) and absorbent of phenolic compounds (polyvinylpyrrolidone, PVP) are presented in final amounts.

Preparation of primary explants and initiation of primary culture

In vitro cultures were initiated from apical and axillary buds taken from donor plants during dormancy (December 2017-January 2018, BBCH00), buds opening (May 2018, BBCH07), and fruit ripening (September-October 2018, BBCH81). Individual buds were separated, rinsed in deionized water and transferred to aseptic conditions in a laminar flow cabinet. Separated buds were surface sterilized by immersing buds in 1\% sodium hypochlorite (Na$\mathrm{ClO}$ ) for 1 (bud opening) or 2 (fruit ripening, dormancy) minutes, followed by immersion in a $0.3 \%$ agar solution with $25 \mathrm{ml} \mathrm{l}^{-1}$ of PPM (Plant Preservative Mixture) for 5 minutes and then rinsing three times in deionized water. Subsequently, outer bud scales and residue of wood tissues were removed and the initiation of primary in vitro culture was carried out.

\section{Cultivation of in vitro cultures and multiplication}

Glass jars with tissue cultures were maintained in controlled conditions at $24{ }^{\circ} \mathrm{C} \pm 1{ }^{\circ} \mathrm{C}$ during the day and $20^{\circ} \mathrm{C} \pm 1{ }^{\circ} \mathrm{C}$ at night with a light cycle of 16 hours light (day) and 8 hours dark (night), 90\% relative humidity, and $50 \mu \mathrm{mol} \mathrm{m} \mathrm{m}^{-2} \mathrm{~s}^{-1}$ light intensity, as provided by white neon tubes (Philips MASTER TL-D Super 80 36W/840, Philips Lighting, Netherlands).

Six weeks after the initiation of primary culture, the regenerated microshoots were separated, cut into $1-2 \mathrm{~cm}$ segments and placed on the multiplication medium (Table $3)$. Subsequently, every 6 weeks the microshoots were sep- arated, cut into 1-2 $\mathrm{cm}$ segments and utilized for further sub-culturing.

The growth and development of explants during the multiplication phase (number of shoots per explant, shoots length) were evaluated after the $4^{\text {th }}$ sub-cultivation. Simultaneously, the concentration of chlorophyll $\mathrm{a}+\mathrm{b}$ and hydrogen peroxide in the plant material was determined.

\section{Statistical analysis}

Results were calculated as means \pm standard error (SE) of six $(n=6)$ replicates (for parameters determined in leaves from one mother plant and regenerated shoots, each from individual explants). The concentration of leaf metabolites (chlorophyll $\mathrm{a}+\mathrm{b}$, hydrogen peroxide, total phenolic acids, flavonoids and tannins) in mother plants of nine Magnolia species in the stage of fruit formation/ripening as well as metabolites (chlorophyll $\mathrm{a}+\mathrm{b}$, hydrogen peroxide) analysed in the regenerated shoots of explants at the fourth multiplication, as combined with their production parameters (shoot number per explant, shoot length), were evaluated by one-way ANOVA. Comparison among the means was performed using Duncan's multiple range test. Connecting letters indicate significant differences between treatments at the confidence level of $\mathrm{P} \leq 0.05$. Thereafter, regression analyses of relationships between respective mother plant leaf metabolites and the efficiency of the primary culture derivation, as well as between explant leaf metabolites and production parameters were carried out and Pearson's regression coefficients were calculated. 


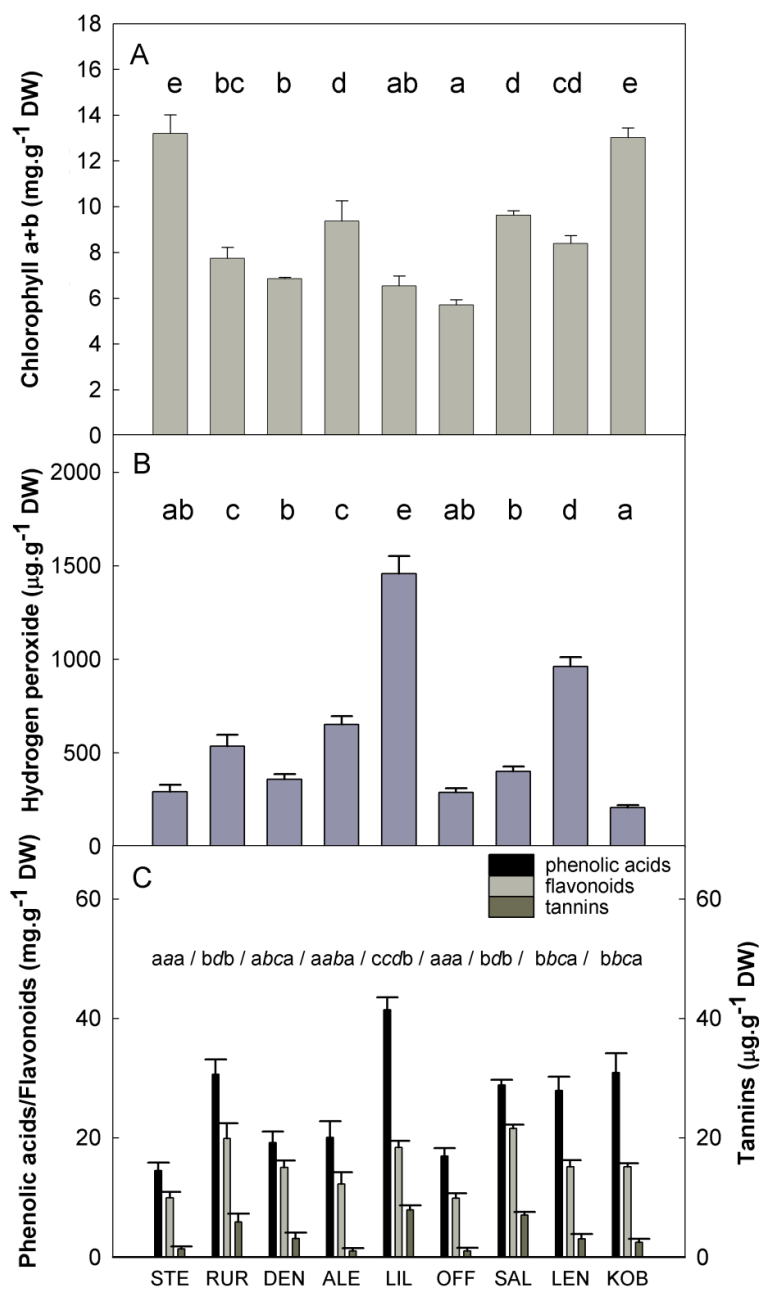

Fig. 1. Concentration of leaf metabolites in explant donor plants of nine Magnolia genotypes, as collected in the fruit ripening phase $(\mathrm{BBCH} 81)$. Letters indicate statistically significant differences at the confidence level $\mathrm{P} \leq 0.05$. STE, Magnolia stellata; RUR, M. $\times$ soul. 'Rustica Rubra'; DEN, M denudate; ALE, $M$. × soul. 'Alexandrina'; LIL, M. liliiflora; OFF, M. officinalis var. biloba; SAL, M. salicifolia; LEN, M. $\times$ soul. 'Lennei'; KOB, M. kobus.

\section{Results}

The donor plants of nine Magnolia species markedly differed in the leaf chlorophyll $\mathrm{a}+\mathrm{b}$ concentration (Fig. 1A). The largest values showed that M. stellata and M. kobus (greater than than $13 \mathrm{mg} \mathrm{g}^{-1} \mathrm{DW}$ on average) had the highest concentration of chlorophyll $\mathrm{a}+\mathrm{b}$ and $M$. officinalis var. biloba had the lowest (less than half of the average concentration)

On the other hand, M. liliiflora and $M . \times$ soul 'Lennei' had the highest leaf hydrogen peroxide concentration (Fig. 1B). The lowest level was found in M. kobus (ca. $200 \mu \mathrm{g}$ $\left.\mathrm{g}^{-1} \mathrm{DW}\right)$

The highest phenolic acid content was exhibited by $M$. liliiflora (ca. $40 \mathrm{mg} \mathrm{g}^{-1} \mathrm{DW}$ ), then $M$. $\times$ soul. 'Rustica Rubra', M. salicifolia, $M . \times$ soul. 'Lennei' and M. kobus with ca. $30 \mathrm{mg} \mathrm{g}^{-1} \mathrm{DW}$, and finally M. stellata, M. denudata, M. $\times$ soul. 'Alexandrina' and $M$. officinalis var. biloba, reaching only concentrations of round $20 \mathrm{mg} \mathrm{g}^{-1} \mathrm{DW}$ (Fig. 1C).

The concentration of flavonoids was generally lower than those of phenolic acids. Magnolia $\times$ soul. 'Rustica Rubra' and M. salicifolia with ca. $20 \mathrm{mg} \mathrm{g}^{-1} \mathrm{DW}$ had the highest flavonoid concentration. M. stellata and M. officinalis var. biloba had the lowest flavonoid levels (only a half).

When comparing the leaf tannin content, two distinct groups of Magnolia genotypes were observed. M. $\times$ soul. 'Rustica Rubra', M. liliiflora and M. salicifolia contained $7 \mu \mathrm{g} \mathrm{g}^{-1} \mathrm{DW}$ of tannin and the remaining genotypes had concentrations ranging from 1 to $3 \mu \mathrm{g} \mathrm{g}^{-1} \mathrm{DW}$.

When evaluating the efficiency of primary in vitro culture initiation (Table 5), the best results for M. stellata were obtained on the SA1 medium with the meristems collected at the bud opening stage $(18 \%) . M . \times$ soul. 'Rustica Rubra' responded best to MS2 medium (50\%), M. denudata to MS4 medium (36\%), M. × soul. 'Alexandrina' to SA1 and MS3 (100\%), M. salicifolia to MS1 (25\%) and M. officinalis var. biloba, M. × soul. 'Lennei' and M. kobus to MS3 (20, 43 and 8\%, respectively), all at the same meristem collecting time. The largest success in M. liliiflora was observed on the MS3 medium with meristems collected at the dormancy stage $(40 \%)$. Regression analysis of relationships between average efficiency of primary in vitro derivation at the fruit ripening stage and leaf metabolite levels (Table 6) revealed a high positive correlation with total tannins $(r=0.833)$.

Multiplicated explants of $M . \times$ soul. 'Alexandrina' showed the highest chlorophyll $\mathrm{a}+\mathrm{b}$ concentration (Fig. $2 \mathrm{~A}$ ) on both SAB0.5 media (nearly $4 \mathrm{mg} \mathrm{g}^{-1} \mathrm{DW}$ ). Doubling the concentration of BAP (SAB1) caused a reduction by half in this metabolic parameter. In M. × soul. 'Lennei,' the highest chlorophyll $\mathrm{a}+\mathrm{b}$ level was found on the SAB1PVP medium (ca. $6 \mathrm{mg} \mathrm{g}^{-1} \mathrm{DW}$ ).

The highest concentration of leaf hydrogen peroxide (ca. $600 \mu \mathrm{g} \mathrm{g}^{-1} \mathrm{DW}$ ) in cultivar 'Alexandrina' was identified on the SAB1-PVP medium (Fig. 2B). Its concentration decreased with the level of BAP and PVP in the multiplication medium. The opposite reaction was found in the cultivar 'Lennei' with the $\mathrm{H}_{2} \mathrm{O}_{2}$ level decreasing from approximately 400 to $200 \mu \mathrm{g} \mathrm{g}^{-1} \mathrm{DW}$.

The shoot number per explant (Fig. 2C) was relatively stable in cv. 'Alexandrina' (almost 2) and only fell below 1.5 on the SAB1 medium. In the cv. 'Lennei', this parameter reached approx. 1.1 on SAB0.5 and SAB1 media, but on media supplemented with PVP the shoot number doubled.

The shoot lengths (Fig. 2D) in explants of the cultivar 'Alexandrina' were around $5 \mathrm{~mm}$. However, on the SAB0.5 medium they were ca. $8 \mathrm{~mm}$. The cultivar 'Lennei' grew faster and reached ca. $12-14 \mathrm{~mm}$ on SAB0.5 and SAB1PVP media, but only grew to ca. $10 \mathrm{~mm}$ on the SAB1 medium.

Chlorophyll $\mathrm{a}+\mathrm{b}$ concentration was highly correlated (Table 7) with the shoot number per explant and shoot length in multiplicated explants in the cv. 'Alexandrina'(r $=0.782$ and 0.712 , respectively). However, in the cv. 'Lennei' these relationships were even stronger $(r=0.876$ and 0.998 , respectively). On the other hand, there was a high 
Table 5. Efficiency of primary in vitro culture initiation (PCI) from the apical/axillary meristem of nine Magnolia genotypes, as collected in the stage of dormant buds (December 2017-February 2018, BBCH 00), bud opening (May 2018, BBCH 07), and fruit ripening (September-October 2018, BBCH 81) on different initiation media

\begin{tabular}{|c|c|c|c|c|c|c|c|}
\hline \multirow{2}{*}{ Genotype } & \multicolumn{7}{|c|}{ Initiation medium } \\
\hline & SA1 & SB1 & MS1 & MS2 & MS3 & MS4 & Average \\
\hline \multicolumn{8}{|c|}{ Efficiency of PCI at BBCH 00 / BBCH 07 / BBCH 81 (\%) } \\
\hline STE & $0 / 18 / 0$ & $0 / 0 / 0$ & $7 / 13 / 0$ & $0 / 8 / 0$ & $0 / 8 / 0$ & $0 / 6 / 0$ & $1 / 9 / 0$ \\
\hline RUR & $10 / 23 / 0$ & $0 / 33 / 0$ & $0 / 8 / 0$ & $0 / 50 / 0$ & $0 / 30 / 0$ & $10 / 18 / 40$ & $3 / 27 / 7$ \\
\hline DEN & $0 / 25 / 0$ & $0 / 7 / 0$ & $20 / 27 / 0$ & $20 / 8 / 0$ & $0 / 27 / 0$ & $0 / 36 / 0$ & $7 / 22 / 0$ \\
\hline ALE & $0 / 100 / 0$ & $0 / 50 / 0$ & $0 / 0 / 0$ & $0 / 0 / 0$ & $0 / 100 / 0$ & $0 / 0 / 17$ & $0 / 41 / 3$ \\
\hline LIL & $0 / 0 / 0$ & $0 / 33 / 0$ & $0 / 0 / 9$ & $25 / 0 / 9$ & $40 / 0 / 18$ & $0 / 0 / 0$ & $11 / 6 / 6$ \\
\hline OFF & $0 / 14 / 0$ & $0 / 14 / 0$ & $0 / 0 / 0$ & $0 / 17 / 0$ & $0 / 20 / 0$ & $0 / 17 / 0$ & $0 / 14 / 0$ \\
\hline SAL & $11 / 22 / 0$ & $18 / 5 / 0$ & $20 / 25 / 0$ & $11 / 19 / 11$ & $20 / 18 / 0$ & $18 / 5 / 22$ & $16 / 16 / 6$ \\
\hline LEN & $0 / 23 / 0$ & $0 / 25 / 0$ & 0/19/0 & $0 / 38 / 0$ & $0 / 43 / 0$ & $8 / 41 / 0$ & $3 / 31 / 0$ \\
\hline KOB & $0 / 0 / 0$ & $0 / 0 / 0$ & $0 / 0 / 0$ & $0 / 0 / 0$ & $0 / 8 / 0$ & $0 / 0 / 0$ & $0 / 1 / 0$ \\
\hline
\end{tabular}

STE, Magnolia stellata; RUR, M. × soulangeana 'Rustica Rubra'; DEN, M. denudate; ALE, M. × soulangeana 'Alexandrina'; LIL, M. liliiflora; OFF, M. officinalis var. biloba; SAL, M. salicifolia; LEN, M. $\times$ soulangeana 'Lennei'; KOB, M. kobus; SA1 and SB1 - Standardi and Catalano medium in modifications; MS1-4 - Murashige and Skoog medium in modifications (for details on composition see the Materials and methods).

Table 6. Pearson's correlation coefficient (r) for relationships between leaf metabolic parameters of the donor plants and efficiency of primary in vitro culture initiation (average from different initiation media) at the fruit ripening stage of nine Magnolia genotypes

\begin{tabular}{cc}
\hline Parameter & $\begin{array}{c}\text { Efficiency of the } \\
\text { primary culture } \\
\text { initiation } \\
(\%)\end{array}$ \\
\hline $\begin{array}{c}\text { Chlorophyll a+b } \\
\left(\mathrm{mg} \mathrm{g}^{-1} \mathrm{DW}\right) \\
\text { Hydrogen peroxide } \\
\left(\mu \mathrm{g} \mathrm{g}^{-1} \mathrm{DW}\right)\end{array}$ & -0.274 \\
$\begin{array}{c}\text { Phenolic acids }\left(\mathrm{mg} \mathrm{g}^{-1} \mathrm{DW}\right) \\
\text { Flavonoids }\left(\mathrm{mg} \mathrm{g}^{-1} \mathrm{DW}\right)\end{array}$ & 0.456 \\
Tannins $\left(\mu \mathrm{g} \mathrm{g}^{-1} \mathrm{DW}\right)$ & 0.647 \\
\hline
\end{tabular}

*high correlation $(0.7 \leq \mathrm{r}<0.9)$. negative correlation of shoot length with hydrogen peroxide concentration in the cultivar 'Alexandrina' $(\mathrm{r}=-0.763)$.

\section{Discussion}

Effects of culture media composition and plant growth regulator concentration on the initiation of primary tissue culture

The success of regeneration processes under in vitro conditions depends on a complex of internal and external factors (KAMENICKÁ and VÁLKA, 1997). The effect of growth regulators on proliferation and rooting of tissue cultures also depends on genotype (BIEDERMAN, 1987; KAMENICKÁ and LANÁKovÁ, 2000; PARris et al., 2012). Some works (RADOMIR, 2012; NAKAMURA et al., 1995) pointed to genotype-specific requirements of primary explants during the initiation phase of cultivation.

Table 7. Pearson's correlation coefficient (r) for relationships between leaf metabolic and production parameters (at the fourth multiplication cycle) of Magnolia genotypes on different multiplication media

\begin{tabular}{ccc}
\hline Parameter & Shoot no. per explant & $\begin{array}{c}\text { Shoot length } \\
(\mathrm{mm})\end{array}$ \\
\hline M. $\times$ soulangeana 'Alexandrina' & & $0.712^{*}$ \\
Chlorophyll a $+\mathrm{b}\left(\mathrm{mg} \mathrm{g}^{-1} \mathrm{DW}\right)$ & $0.782^{*}$ & $-0.763^{*}$ \\
Hydrogen peroxide $\left(\mu \mathrm{g} \mathrm{g}^{-1} \mathrm{DW}\right)$ & -0.191 & $0.998^{* *}$ \\
$M . \times$ soulangeana Lennei' $^{-1}$ & $0.876^{*}$ & -0.124 \\
Chlorophyll a+b $\left(\mathrm{mg} \mathrm{g}^{-1} \mathrm{DW}\right)$ & -0.632 & \\
Hydrogen peroxide $\left(\mu \mathrm{g} \mathrm{g}^{-1} \mathrm{DW}\right)$ & & \\
\hline
\end{tabular}

*high correlation $(0.7 \leq \mathrm{r}<0.9), * *$ very high correlation $(0.9 \leq \mathrm{r}<1.0)$. 


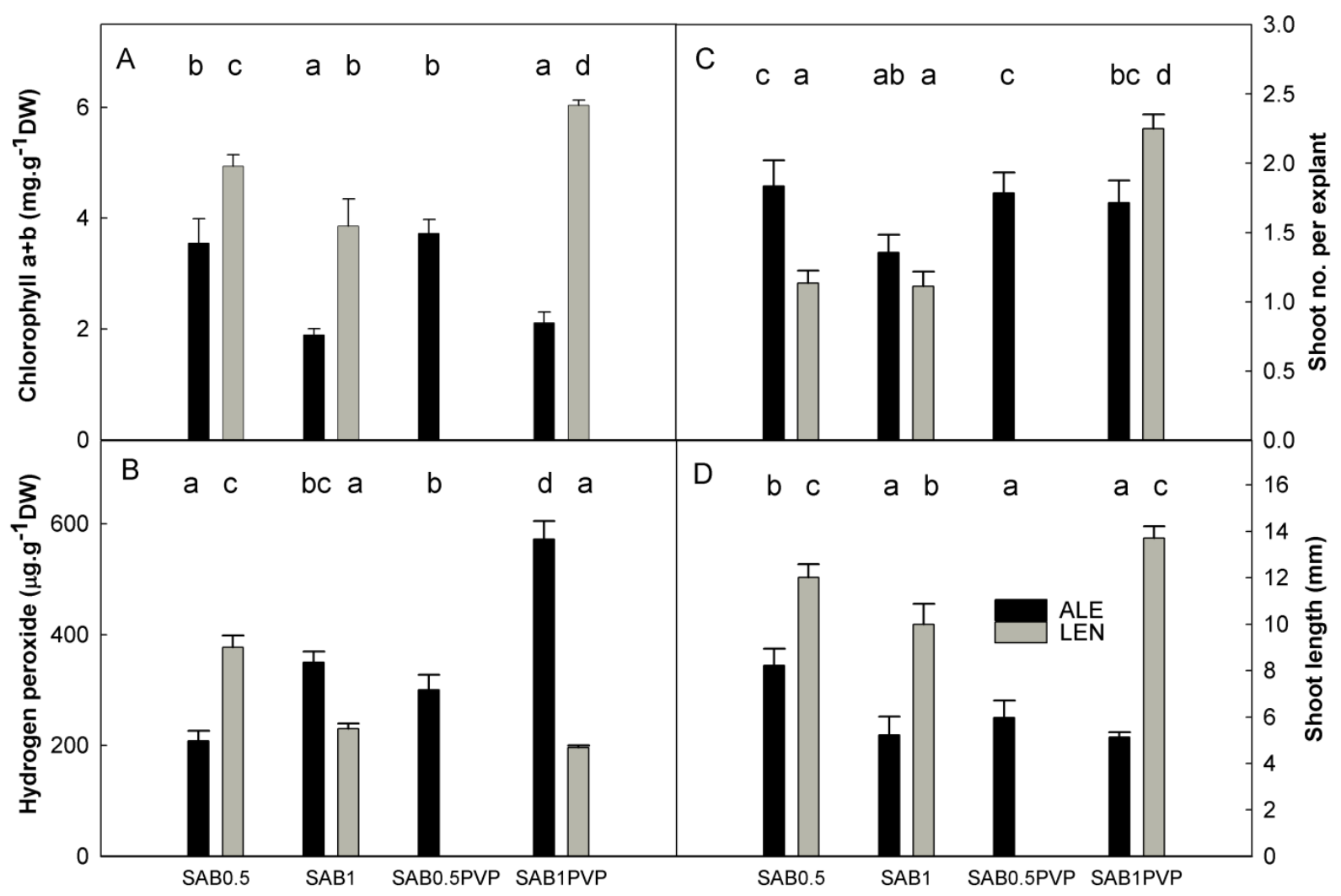

Fig. 2. Leaf chlorophyll $\mathrm{a}+\mathrm{b}(\mathrm{A})$, hydrogen peroxide concentration (B), and production parameters [shoot no. per explant (C), shoot length (D)] in explants of two Magnolia genotypes on different multiplication media (at the fourth multiplication). Letters indicate statistically significant differences at the confidence level $\mathrm{P} \leq 0.05$. ALE, $M$. $\times$ soul. 'Alexandrina', LEN, $M . \times$ soul. 'Lennei'; SAB0.5/1 - Standardi and Catalano medium with the addition of 6-benzylaminopurine and concentration of $0.5 / 1 \mathrm{mg} \mathrm{l}^{-1}$, PVP - polyvinylpyrrolidone.

The age of donor plants, physiological age of explants, as well as the developmental stage of explants are important factors for culture initiation. Tissues and meristems of donor plants have high morphogenetic abilities for a specific period during the annual vegetation cycle. Spring is the optimal season for morphogenesis of most trees (KAMENICKÁ and VÁLKA, 1997). In our study, we achieved the highest efficiency of primary culture initiation of seven Magnolia genotypes (with the exception of M. liliiflora and M. salicifolia) from primary explants collected in the stage of bud opening. In the case of M. liliiflora, the highest efficiency was recorded in the stage of dormant buds. Similar results have been reported by RADOMIR (2012) in a work focused on in vitro propagation of $M$. stellata and $M . \times$ soulangeana. Tissue cultures of M. salicifolia attained a similar efficiency of primary culture initiation from explants collected during the stage of dormant buds and the bud opening stage. In the stage of fruit ripening, the efficiency of primary culture initiation was very low (less than 10\%) in all selected genotypes.

Individual Magnolia species and cultivars have different requirements for the composition of cultivation media (KAMENICKÁ and LANÁKOVÁ, 2000). The MS medium (Murashige and SKoog, 1962) is commonly used for micropropagation of various Magnolia genotypes (BIEDERman, 1987; KAMENICKÁ and LANÁKová, 2000; PARRIS et al., 2012; RADOMIR, 2012; SoKolov et al., 2014; WoJTANIA et al., 2015). Some species and cultivars of magnolias were successfully cultivated and propagated on the $\mathrm{S}_{2}$ (Standardi and Catalano, 1985) medium (KameniCKÁ and VÁLKA, 1997; KAMENICKÁ and LANÁKová, 2000; KoNôPKové, 2007). However, micropropagation of Magnolia is relatively difficult. In our experiment, efficiency of primary culture initiation did not exceed more than $20 \%$ on any of the selected cultivation media in three studied genotypes, M. stellata, M. officinalis var. biloba and $M$. kobus. We didn't observe any marked difference in this parameter in $M$. × soulangeana 'Rustica Rubra' and $M$. salicifolia on any media. Primary explants of $M . \times$ soulangeana 'Lennei' regenerated well on all selected cultivation media. However, the regeneration potential was highest on the MS medium. For some genotypes, $M$. stellata, $M$. denudata and M. kobus, SB1 modification of the $\mathrm{S}_{2}$ medium was the least appropriate.

In vitro growth and development of magnolias is dependent on the exogenous addition of plant growth regulators (PGR) and the requirements for type and concentration of PGRs differs based on the initiation, multiplication and rooting stage (BIEDERMANN, 1987; KAMENICKÁ and VÁLKA, 1997; KAMENICKÁ and LANÁKOVÁ, 2000; MARINESCU, 2008; PARris et al., 2012; RAdOMIR, 2012; SoKolov et al., 2014). BAP (6-benzylaminopurine) is considered 
the most effective cytokinin for the in vitro cultivation of magnolias. The optimal concentration of BAP ranges between $0.25-5.0 \mathrm{mg} \mathrm{l}^{-1}$ and is genotype-specific (KAMENICKÁ and LANÁKová, 2000; PARris et al., 2012; RAdOMIR, 2012; SoKOLOv et al., 2014). Our results are consistent with these statements. Usually, low concentrations of auxins [1-naphtaleneacetic acid (NAA) or indole-3-butyric acid (IBA)] are added to the basal media for initiation of primary cultures. Some authors (NAKAMURA et al., 1995; SoKolov et al., 2014) reported that even low concentration of NAA in media caused browning of explants and undesirable callus formation. In contrast, we didn't observe this complication when NAA was added to the initiation media.

\section{Relationship between leaf metabolites in the donor plants and success of primary culture initiation}

A high positive correlation was found between total tannins $(r=0.833)$, as well as total flavonoids $(r=0.781)$ and efficiency of primary culture initiation at the fruit ripening stage. Flavonoids and tannins are secondary metabolites categorized as phenolic compounds (SAMANTA et al., 2011; Constabel et al., 2014). Plants synthesize flavonoids in root and shoot tissues during normal growth and development. Differences in the content of flavonoids in individual plant parts may be due to hormonal content, the specific metabolic, or endogenous physiological changes in the plants (BhATTACHARYYA et al., 2014). Flavonoids protect plants against various biotic and abiotic stresses and play an important role in the interaction between plants and their environment (Pourcel et al., 2007). Flavonoids are also capable of absorbing harmful UV radiation (TAKAHASHI and OHNISHI, 2004) and are responsible for flower colours (YAO et al., 2004; GRIESBACH, 2005). Tannins are often found in roots, bark, stems, leaves (PoRTER, 1988), fruits and seeds of many plants (FurLAN et al., 2010). The concentration of tannins in leaves of forest trees is dependent on the developmental stage, tissue and environmental conditions (BARBEHENN and CONSTABEL, 2011). There is considerable genotype-specific variation in tannin concentration within 'Magnolia' species (OsIER and LinDROTH, 2006). The main function of tannins is to provide protection against microbial pathogens, harmful insects and herbivores (FURLAN at al., 2010). It is possible that the antimicrobial effect of flavonoids and tannins is responsible for the positive relationship between the concentration of these compounds and efficiency of primary culture initiation, because bacterial contamination is a major problem in this stage of micropropagation.

On the other hand, the release of phenolic compounds from explants to cultivation media and their subsequent oxidation is also a common complication in the micropropagation of plants. Oxidized phenolic compounds inhibit enzyme activity and results in browning of the culture media and explains rooting deficiencies (ARNALDOS et al., 2001).
Effect of BAP concentration and PVP presence in the cultivation media on the multiplication process of $M . \times$ soulangeana cultivars 'Alexandrina' and 'Lennei'

The most appropriate cytokinin for multiplication of magnolias is 6-benzylaminopurine (BAP). However, higher concentrations of BAP (more than $2.5 \mathrm{mg} \mathrm{l}^{-1}$ ) caused browning of the explants, hyperhydricity and lower shoot quality (BAIRU et al., 2007; Aмоo et al., 2011; SoKolov et al., 2014). Some researchers found that tissue culture of $M . \times$ soulangeana showed the highest efficiency of micropropagation on media supplemented with $0.5 \mathrm{mg}^{-1} \mathrm{BAP}$ (MARINEsCu et al., 2008; RAdOMIR, 2012). SoKOLOV et al. (2014) reported that the addition of an auxin (NAA) is required for the multiplication of Magnolia tissue cultures. Nevertheless, we observed the opposite effect of NAA addition to the multiplication media. Tissue cultures of both studied genotypes showed lower shoot formation and length of shoots on media supplemented with NAA (data not shown).

BAP concentrations of $0.5 \mathrm{mg} \mathrm{l}^{-1}$ seem to be the most appropriate for multiplication of $M . \times$ soulangeana 'Alexandrina'. The highest number of shoots per explant, longest shoot length and highest chlorophyll $\mathrm{a}+\mathrm{b}$ content was found on the SAB0.5 medium (0.5 $\left.\mathrm{mg}^{-1} \mathrm{BAP}\right)$. In contrast to our results, GABRYSZEWSKA (1997) reported higher shoot formation in $M . \times$ soulangeana 'Alexandrina' tissue cultures when the concentration of BAP increased from 0.5 to $1.5 \mathrm{mg} \mathrm{l}^{-1}$. The number of shoots per explant and chlorophyll $\mathrm{a}+\mathrm{b}$ content decreased with higher concentrations of BAP. Conversely, the hydrogen peroxide level increased with higher BAP concentrations. The presence of PVP in the media did not show any positive effects on any of the monitored parameters.

In the case of $M . \times$ soulangeana 'Lennei', a higher BAP concentration $\left(1.0 \mathrm{mg} \mathrm{l}^{-1}\right)$ and presence of PVP in the cultivation medium significantly stimulated the number of shoots per explant and increased chlorophyll $\mathrm{a}+\mathrm{b}$ content. Similar to the results of our study, Parris et al. (2012) reported that in Magnolia 'Ann', media supplemented with phenolic binding agents (PVP or activated charcoal) produced greener leaves and increased shoot lengths, but reduced shoot multiplication and rooting initiation. Significantly more shoots per explant, a significantly longer shoot length, and a significantly higher concentration of chlorophyll $\mathrm{a}+\mathrm{b}$ were observed on the SAB1-PVP medium than the SAB1 medium, when comparing those media with or without the addition of PVP (SAB1/SAB1-PVP). A higher BAP concentration, independent of PVP presence, led to a decrease in hydrogen peroxide concentration.

A high positive correlation between chlorophyll $\mathrm{a}+\mathrm{b}$ and the number of shoots per explant $(\mathrm{r}=0.782)$, as well as shoot length $(\mathrm{r}=0.712)$, were observed in $M . \times$ soulangeana 'Alexandrina'. In the case of cv. 'Lennei', the correlation between chlorophyll $\mathrm{a}+\mathrm{b}$ and the number of shoots per explant was high $(\mathrm{r}=0.876)$, while the correlation between chlorophyll $\mathrm{a}+\mathrm{b}$ and shoot length was very high $(\mathrm{r}$ $=0.998$ ). Addition of the plant growth regulators into the cultivation media may cause changes in the physiology 
and biochemical processes of plant cells. Consequently, metabolic disturbances promoting the accumulation of reactive oxygen species (ROS), including $\mathrm{H}_{2} \mathrm{O}_{2}$, occur $(\mathrm{Oz}-$ DEN and KaraAslan, 2011). Production of ROS can cause growth inhibition, programmed cell death (PCD) and can alter plant developmental pathways leading to poor regeneration of plants. Plant recalcitrance during in vitro cultivation has also been associated with ROS production (Benson, 2000; GuPTA, 2010).

\section{Conclusion}

We can conclude that in vitro propagation of magnolias is difficult. The most critical point of the initiation phase is culture contamination, which occurred in spite of surface sterilization and the addition of PPM, as a biocide, into the cultivation media. The developmental stage of primary explants plays an important role in this phase. In the case of seven Magnolia genotypes (with the exception of $M$. liliiflora and M. salicifolia), the bud opening stage was the most appropriate for initiation of primary cultures. The concentration of total tannins in leaves (in the fruit ripening stage) also had a significant influence on the success of primary culture initiation $(\mathrm{r}=0.833)$. The requirements of Magnolia taxa for the composition of basal media and the type and concentration of plant growth regulators in the initiation and multiplication stages of micropropagation are genotype-specific. Standardi and Catalano medium $\left(\mathrm{S}_{2}\right)$ with $0.5 \mathrm{mg} \mathrm{l}^{-1}$ of BAP is the most suitable for multiplication of $M . \times$ soulangeana 'Alexandrina', however, cultures of $M . \times$ soulangeana 'Lennei' proliferated and grew better on $\mathrm{S}_{2}$ medium with $1.0 \mathrm{mg} \mathrm{l}^{-1}$ of BAP and $1.0 \mathrm{~g} \mathrm{l}^{-1}$ polyvinylpyrrolidone.

\section{Acknowledgement}

This work was supported by the Scientific Grant Agency under VEGA 2/0072/16.

\section{References}

Amoo, S.O., Finnie, J.F., Van Staden, J., 2011. The role of meta-topolins in alleviating micropropagation problems. Plant Growth Regulation, 63: 197-206.

ANDERSON, W.C., 1980. Tissue culture propagation of red and black raspberries, Rubus idaeus and R. occidentalis. Acta Horticuluturae, 112: 13-20.

Arnaldos, T.L., Munoz, R., Ferrer, M.A., Calderon, A.A., 2001. Changes in phenol content during strawberry (Fragaria $\times$ ananasa, cv. Chandler) callus culture. Physiologia Plantarum, 113: 315-322.

Bairu, M.W., Stirk, W.A., Dolezal, K., Van Staden, J., 2007. Optimizing the micropropagation protocol for the endangered Aloe polyphylla: can meta-topolin and its derivatives serve as replacement for benzyladenine and zeatin? Plant Cell, Tissue, and Organ Culture, 90: 15-23.

Barbehenn, R.V., Constabel, C.P., 2011. Tannins in plantherbivore interactions. Phytochemistry, 72: 1551-1565.

Benson, E., 2000. Do free radicals have role in plant tissue culture recalcitrance? Vitro Cellular and Developmental
Biology - Plant, 36: 163-170.

Bhattacharyya, P., Kumaria, S., Diengdoh, R., Tandon, P., 2014. Genetic stability and phytochemical analysis of the in vitro regenerated plants Dendrobium nobile Lindl., an endangered medicinal orchid. Meta Gene, 2: 489-504.

Bi, Y., GaO, S., QiaO, Y., Liu, S., CaO, H., Zhang, H., 2002. Effect of plant growth regulator on tissue culture of Mongolian white yulan. Journal of Hebei Vocation Technical Teachers College, 16:14-15.

BiEDERMAn, I.E.G., 1987. Factors affecting establishment and development of Magnolia hybrids in vitro. Acta Horticulturae, 212: 625-630.

Callaway, D.J., 1994. The world of magnolias. Portland: Timber Press. 260 p.

ChÉE, R., Pool, R.M., 1987. Improved inorganic media constituents for in vitro shoot multiplication of Vitis vinifera. Scientia Horticulturae, 32: 85-95.

Constabel, C.P., Yoshida, K., Walker, W., 2014. Diverse ecological roles of plant tannins: plant defence and beyond. In Romani, A., LatTanzio, V., Quideau, S. (eds). Recent advances in polyphenol research. Vol. 4. Oxford: John Wiley \& Sons, p. 115-142.

Figlar, R B., Noоteboom, H.P., 2004. Notes on Magnoliaceae IV. Blumea, 49: 1-14.

Filoví, A., KonôPKová, J., Bošiaková, D., 2018a. Characterization of growth and development of explantate cultures for Magnolia liliiflora Desr. and Liriodendron tulipifera L. 'Auromarginatum'. In Recenzovaný zbornik vedeckých prác Slovenskej spoločnosti pre pol'nohospodárske, lesnicke, potravinárske a veterinárske vedy pri Slovenskej akadémii vied, pobočka Nitra. Nitra: Slovenská pol'nohospodárska univerzita, p. 109-117.

Filoví, A., Konôpková, J., Bošiaková, D., 2018b. Morfologicko-anatomické zmeny explantátovej kultúry Magnolia $\times$ soulangiana $\mathrm{v}$ podmienkach nadbytku iónov $\mathrm{Al}^{3+}$ a $\mathrm{Ca}^{2+}$ [Morphological-anatomical changes of explantate culture of Magnolia $\times$ soulangiana in conditions of elevated $\mathrm{Al}^{3+}$ and $\mathrm{Ca}^{2+}$. In Vliv abiotických a biotických stresorü na vlastnosti rostlin 2018: sborník recenzovaných védeckých prací. Praha, Zvolen: Česká zemědelská univerzita v Praze, Ústav ekológie lesa, p. 78-83.

Furlan, C.M., Motta, L.B., Cursino dos Santos, D.Y.A., 2010. Tannins: what do they represent in plant life? In PETRIDIS, G.K. (eds). Tannins: types, foods containing, and nutrition. Nova Science Publishers, p. 1-13.

GabryszewsKa, E., 1997. Wplyw tidiazuronu i cytokinin na wzrost a rozwój pedów Magnolia $\times$ soulangiana 'Alexandrina' in vitro [Influence of tidiazuron and cytokinin on the growth and development in Magnolia $\times$ soulangiana 'Alexandrina' shoots in vitro]. In DubERT, F., SKocZOWSKI, A. (eds). Zastosowanie kultur in vitro $w$ fizjologii roślin. Kraków: PAN, p. 79-82.

Gamborg, O.L., Miller, R.A., Ojima, K., 1968. Nutrient requirements of suspension cultures of soybean root cells. Experimental Cell Research, 50: 151-158.

GuPTA, S.D., 2010. Role of free radicals and antioxidants in in vitro morphogenesis. In GUPTA, S.D. (eds). Reactive oxygen species and antioxidants in higher plants. Kharagpur: Science Publishers, p. 229-247.

HoŤKa, P., BARTA, M., 2012. Dreviny Arboréta Mlyňany SAV [Tree species in the Arboretum Mlynnany of the Slovak Academy of Sciences]. Bratislava: Veda. 132 p.

KamenickÁ, A., LANÁKová, M., 2000. Effects of culture medium composition and vessel type on axillary shoot formation of Magnolia in vitro. Acta Physiologiae Plantarum, 22: 129-134.

KAMENICKÁ A., VÁLKA, J., 1997. Cultivation and propagation of magnolias. Zvolen: Ústav ekológie lesa SAV. 99 p. 
Kester, D.E., Davies, F.T., Geneve, R.L., 2002. Hartmann and Kester's plant propagation: principles and practices. Upper Saddle River, New Jersey: Pearson Education. 880 p.

Kolimárová, Ž., Balážová, E., Č́emanová, H., HalušKa, M., ZÁborská, Z., Schvalb, M., 2016. Program rozvoja mesta Lučenec 2016-2022 (2025) [Development program 2016-2022 (2025) of the city of Lučenec]. [cit. 2019-11-26]. https://www.lucenec.sk/download file_f. php?id $=810658$

KonôPKová, J., 2007. Využitie in vitro metód pri rozmnožovaní magnólie soulangovej (Magnolia $\times$ soulangiana Soul.-Bod.) v Arboréte Mlyňany SAV [In vitro methods in propagation of the Saucer magnolia (Magnolia $\times$ soulangiana Soul-Bod.) in Arboretum Mlyňany SAS]. In Zbornik referátov z vedeckej konferencie "Aklimatizácia a introdukcia drevín v podmienkach globálneho oteplovania". Vieska nad Žitavou: Arborétum Mlyňany SAV, p. 196-203.

LiCHTANTAHLER, H.K., 1987. Chlorophylls and carotenoids: photosynthetic biomembranes. Methods in Enzymology, 148: 350-382.

Lloyd, G., McCown, B., 1980. Commercially-feasible micropropagation of mountain laurel, Kalmia latifolia, by use of shoot-tip culture. Combined Proceedings, International Plant Propagators' Society, 30: 41-427.

Magic, D., 1986. Map-part Fil'akovo. In Michalko, J., MaGIC, D., Berta, J. (eds). Geobotanical map of C. S. S. R. Slovak Socialist Republic. Bratislava: Veda. 186 p.

Marinescu, L., Radomir, A.M., Radu, T., Teodorescu, A., Fleancu, M., Popescu, C., 2008. Preliminary results regarding the influence of cytokinin on micropropagation of Magnolia soulangiana. Lucrări Științifice - Universitatea de Științe Agronomice și Medicină Veterinară București. Seria B, Horticultură, 51: 601-607.

Michalko, J., 1986. Map-part Prievidza. In Michalko, J., Magic, D., Berta, J. (eds). Geobotanical map of C. S. S. R. Slovak Socialist Republic. Bratislava: Veda. 186 p.

Ming, L., Huan-Cheng, M.A., 2003. The review of the asexual propagation on Magnoliaceae. Journal of Southwest Forestry College, 23: 92-96.

Mukherjee, S.P., Choudhuri, M.A., 1983. Implications of water stress-induced changes in the level of endogenous ascorbic acid and hydrogen peroxide in Vigna seedlings. Physiologia Plantarum, 58: 166-170.

Murashige, T., Skoog, F., 1962. A revised medium for rapid growth and bioassay with tobacco tissue cultures. Physiologia Plantarum, 15: 473-497.

Nguyen, P.M., Niemeyer, E.D., 2008. Effects of nitrogen fertilization on the phenolic composition and antioxidant properties of basil (Ocimum basilicum L.). Journal of Agricultural and Food Chemistry, 56 (18): 8685-8691.

Nakamura, K., Wakita, Y., Yokota, S., Yoshizawa, N., IDEI, T., 1995. Induction of multiple shoots by shoot apex culture in Magnolia obovate Thunb. Plant Tissue Culture Letters, 12 (1): 34-40.

OSIER, T.L., LINDROTH, R.L., 2006. Genotype and environment determine allocation to and costs of resistance in quaking aspen. Oecologia, 148: 293-303.

Owen, H.R., Miller, A.R., 1992. An examination and correction of plant tissue culture basal medium formulations. Plant Cell, Tissue, and Organ Culture, 28: 147-150.

Ozden, M., KaraAslan, M., 2011. Effects of cytokinin on callus proliferation associated with physiological and bio- chemical changes in Vitis vinifera L. Acta Physiologiae Plantarum, 33: 1451-1459.

Park, Y.K., Koo, M.H., Ikegaki, M., Contado, J.L., 1997. Comparison of the flavonoid aglycone contents of Apis mellifera propolis from various regions in Brazil. Brazilian Archives of Biology and Technology, 40: 97-106.

Parris, J.K., Touchell, D.H., Ranney, T.G., AdelberG, J., 2012. Basal salt composition, cytokinins, and phenolic binding agents influence in vitro growth and ex vitro establishment of Magnolia 'Ann'. Horticultural Science, 47 (11): $1625-1629$.

Polláková, N., 2018. Soils classified in the Arboretum Mlyňany, Slovakia. Folia Oecologica, 45 (2): 120-128.

Porter, L.J., 1988. Flavans and proathocyanidins. In HARBORNE, J.B. (ed). The flavonoids - recent advances in research since 1980. London: Chapman \& Hall, p. 21-62.

Pourcel, L., Routaboul, J.M., Cheynier, V. et al., 2007. Flavonoid oxidation in plants: from biochemical properties to physiological functions. Trends in Plant Science, 12 (1): 29-36.

Radomir, A.M., 2012. Comparative study on the in vitro multiplication potential of Magnolia stellate and Magnolia $\times$ soulangiana species. Journal of Horticulture, Forestry, and Biotechnology, 16 (2): 39-44.

Samanta, A., DAS, G., DAS, S.K., 2011. Roles of flavonoids in plants. International Journal of Pharmaceutical Science and Technology, 6 (1): 12-35.

Sokolov, R.S., Atanassova, B.Y., Iakimova, E.T., 2014. Physiological response of in vitro cultured Magnolia sp. to nutrient medium composition. Journal of Horticultural Research, 22 (1): 49-61.

Standardi, A., Catalano, F., 1985. Tissue culture propagation of kiwifruit. Combined Proceedings, International Plant Propagators'Society, 34: 236-243.

TÁBOR, I., PAVlaČKa, R., 1992. Arborétum Mlyn̆any - Sprievodca po Arboréte [Arboretum Mlyňany - arboretum guide]. Bratislava: Veda. $62 \mathrm{p}$.

Takahashi, A., Ohnishi, T. 2004. The significance of the study about the biological effects of solar ultraviolet radiation using the exposed facility on the internal space station. Biological Science in Space, 18 (4): 255-260.

Tong, Z., ZHU, Y., WANG, Z., 2002. Studies on tissue culture and the establishment of a high-yield cell line of Magnolia officinalis. Journal Forestry University of Nanjing, 26: $23-26$.

ÚkzÚz, 2013. Stanovení obsahu taninů v čiroku spektrofotometricky [Spectrometric determination of tannin content in sorghum]. [cit. 2019-11-26]. http://eagri.cz/public/web/ file/255266/_50321._1_Stan_obs_taninu_v_ciroku_ spektrofotometricky.pdf

Wojtania, A., SkrzypeK, E., Gabryszevska, E., 2015. Effect of cytokinin, sucrose, and nitrogen salts concentrations on the growth and development and phenolics content in Magnolia $\times$ soulangiana 'Coates' shoots in vitro. Acta Scientarum Polonorum Hortorum Cultus, 14 (3): 51-62.

YAO, L.H., JiANG, Y.M., SHI, J. et al. 2004. Flavonoids in food and their health benefits. Plant Foods and Human Nutrition, 59: 113-122.

Received December 20, 2019 Accepted March 13, 2020 